\title{
Sexually dimorphic effect of aging on skeletal muscle protein synthesis
}

\author{
Gordon I Smith, Dominic N Reeds, Angela M Hall, Kari T Chambers, Brian N Finck and Bettina Mittendorfer*
}

\begin{abstract}
Background: Although there appear to be no differences in muscle protein turnover in young and middle aged men and women, we have reported significant differences in the rate of muscle protein synthesis between older adult men and women. This suggests that aging may affect muscle protein turnover differently in men and women.

Methods: We measured the skeletal muscle protein fractional synthesis rate (FSR) by using stable isotope-labeled tracer methods during basal postabsorptive conditions and during a hyperaminoacidemic-hyperinsulinemiceuglycemic clamp in eight young men (25-45y), ten young women (25-45y), ten old men (65-85y) and ten old women (65-85 y).

Results: The basal muscle protein FSR was not different in young and old men $\left(0.040 \pm 0.004\right.$ and $0.043 \pm 0.005 \% \cdot h^{-1}$, respectively) and combined insulin, glucose and amino acid infusion significantly increased the muscle protein FSR both in young (to $0.063 \pm 0.006 \% \cdot h^{-1}$ ) and old (to $0.051 \pm 0.008 \% \cdot h^{-1}$ ) men but the increase $(0.023 \pm 0.004$ vs. $0.009 \pm 0.004 \% \cdot \mathrm{h}^{-1}$, respectively) was $\sim 60 \%$ less in the old men $(P=0.03)$. In contrast, the basal muscle protein FSR was $\sim 30 \%$ greater in old than young women $\left(0.060 \pm 0.003\right.$ vs. $0.046 \pm 0.004 \% \cdot h^{-1}$, respectively; $\left.P<0.05\right)$ and combined insulin, glucose and amino acid infusion significantly increased the muscle protein FSR in young $(P<0.01)$ but not in old women $(P=0.10)$ so that the FSR was not different between young and old women during the clamp $\left(0.074 \pm 0.006 \% \cdot h^{-1}\right.$ vs. $0.072 \pm 0.006 \% \cdot h^{-1}$, respectively).
\end{abstract}

Conclusions: There is sexual dimorphism in the age-related changes in muscle protein synthesis and thus the metabolic processes responsible for the age-related decline in muscle mass.

Keywords: Muscle protein turnover, Aging, Sarcopenia, Amino acid

\section{Background}

Understanding how aging affects muscle protein metabolism is important in order to devise adequate countermeasures for the age-related loss of muscle mass. It is well known that there is sexual dimorphism with regards to body composition. Healthy adult women have less lean body and muscle mass and more fat than men [1-3] and the age-related decrease in muscle mass is slower in women than in men [1,4-6]. Insight into the mechanism (s) responsible for these differences in phenotype is limited, however. Several studies indicate that there is no difference in the basal rate of muscle protein synthesis [7-11] or muscle protein breakdown [8] or the anabolic

\footnotetext{
* Correspondence: mittendb@wustl.edu

Division of Geriatrics and Nutritional Science, Washington University School of Medicine, 660 South Euclid Avenue; Campus, Box 8031, Saint Louis MO
} 63110, USA responses to nutritional stimuli [11] and resistance exercise [7] in young and middle-aged adult men and women. On the other hand, we have recently found that the basal rate of muscle protein synthesis is greater in obese, old women than in obese, old men [12]. In addition, we found that obese, old women, but not obese, old men, failed to significantly increase the rate of muscle protein synthesis in response to mixed meal ingestion [12]. This suggests that differences in muscle protein turnover between men and women might be most apparent when muscle mass is changing (i.e., during aging vs. earlier adulthood when muscle mass is steady) and that aging affects muscle protein turnover differently in men and women. To our knowledge, only one study so far has evaluated the effect of both sex and aging on basal muscle protein turnover [13]. However,

\section{Biomed Central}


this study was limited to basal, postabsorptive conditions only and included only old men with hypogonadism and old women who had very low serum androgen concentrations, which may have confounded the results. Hypoandrogenemia is associated with a reduced lean body mass [14] and treatment with testosterone increases the muscle protein synthesis rate [15-20].

The primary purpose of our study therefore was to evaluate the effect of aging on the basal rate of muscle protein synthesis and the anabolic response to combined hyperaminoacidemia and hyperinsulinemia in men and women. We hypothesized that: i) the anabolic response to increased amino acid and insulin availability would be reduced in old compared with young subjects (both men and women), ii) the age-related decline in the anabolic response would be greater in women than in men, and iii) the basal rate of muscle protein synthesis would be greater in old compared with young women. We also measured the concentrations of myostatin and follistatin in plasma and the expression of the genes encoding myostatin, myoD and follistatin in muscle to gain information of potential differences in cellular factors that regulate protein synthesis in men and women and young and old subjects. Myostatin is a muscle growth inhibitor which is produced primarily in skeletal muscle cells, circulates in the blood and acts on muscle tissue by blocking genes induced during differentiation (e.g., myoD and myogenin, which are myogenic growth factors [21]) and by inhibiting the anabolic signaling cascade and muscle protein synthesis [22-26]. Follistatin is ubiquitously expressed, circulates in the blood and binds to and thereby inhibits myostatin $[27,28]$. We therefore hypothesized that: i) muscle myostatin gene expression and myostatin concentration in plasma would be greater in old than young subjects and greater in old men than old women whereas ii) muscle myoD and follistatin mRNA expression and plasma follistatin concentration would be greater in young than old subjects and greater in old women than old men.

\section{Methods}

\section{Subjects}

Thirty-eight non-obese subjects (8 men and 10 women who were between 25 and 45 y old and 10 men and 10 women who were between 65 and 85 y old) participated in this study. Data from 8 young men and 8 young women have previously been reported [11]. None of the subjects engaged in regular physical activities (i.e., they exercised $\leq 1.5 \mathrm{~h} \cdot \mathrm{wk}^{-1}$ ) or took medications (including hormonal contraceptives or hormone replacement therapy), and none reported excessive alcohol intake or consumed tobacco products. All subjects were considered to be in good health after completing a comprehensive medical evaluation, which included a history and physical examination, standard blood tests, and an oral glucose (75 g) tolerance test (Table 1). Written informed consent was obtained from all subjects before their participation in the study, which was approved by the Human Research Protection Office at Washington University School of Medicine in St. Louis, MO.

\section{Experimental protocol}

Approximately two weeks before the protein metabolism study, subjects' total body mass, fat mass, fat-free mass (FFM) and appendicular muscle mass (Table 1) were measured by using dual-energy X-ray absorptiometry (Delphi-W densitometer, Hologic, Waltham, MA) [29]. The appendicular muscle mass index, a measure of muscle mass adjusted for individual differences in height was calculated by dividing total appendicular muscle mass $(\mathrm{kg})$ by height squared $\left(\mathrm{m}^{2}\right)$ [30]. Subjects were instructed to adhere to their usual diet and to refrain from vigorous physical activities for three days before the protein metabolism study. We did not control for menstrual cycle phase in our young women because Miller et al. [31] demonstrated that the rate of muscle protein synthesis is not different during the follicular and luteal phases of the menstrual cycle and we [11] have found that there is no relationship between plasma estradiol or progesterone concentrations and the muscle protein FSR in young women. The evening before the study, subjects were admitted to the Clinical Research Unit at Washington University School of Medicine. At $2000 \mathrm{~h}$, they consumed a standard meal providing $50.2 \mathrm{~kJ}$ per $\mathrm{kg}$ body weight (15\% as protein, $55 \%$ as carbohydrates and $30 \%$ as fat). Subjects then rested in bed and fasted (except for water) until completion of the study the next day. At $\sim 0600 \mathrm{~h}$ on the following morning, a cannula was inserted into a vein in the forearm or the antecubital fossa of one arm for the infusion of stable isotope labeled tracers, insulin, glucose, and amino acids; another cannula was inserted into a vein of the contralateral hand (which was warmed to $55^{\circ} \mathrm{C}$ ) to obtain arterialized blood samples. At $\sim 0800 \mathrm{~h}$, primed, constant infusions of $\left[\right.$ ring- $^{2} \mathrm{H}_{5}$ ] phenylalanine (priming dose: $2.8 \mu \mathrm{mol} \cdot \mathrm{kg} \mathrm{FFM}^{-1}$, infusion rate: $0.08 \mu \mathrm{mol} \cdot \mathrm{kg}$ $\mathrm{FFM}^{-1} \cdot \mathrm{min}^{-1}$ ) and $\left[6,6-{ }^{2} \mathrm{H}_{2}\right]$ glucose (priming dose: $18 \mu \mathrm{mol} \cdot \mathrm{kg}$ body $\mathrm{wt}^{-1}$, infusion rate: $0.22 \mu \mathrm{mol} \cdot \mathrm{kg}$ body $\mathrm{wt}^{-1} \cdot \mathrm{min}^{-1}$ ), both purchased from Cambridge Isotope Laboratories Inc. (Andover, MA), were started and maintained for seven hours. Four hours after the start of the tracer infusions, a hyperinsulinemic-hyperaminoacidemiceuglycemic clamp was started and maintained for three hours. Human insulin (Novolin R, Novo Nordisk, Princeton, NJ) was infused at a rate of $20 \mathrm{mU} \cdot \mathrm{m}^{-2}$ body surface area (BSA) $\cdot \mathrm{min}^{-1}$ (initiated with priming doses of $80 \mathrm{mU} \cdot \mathrm{m}^{-2} \mathrm{BSA} \cdot \mathrm{min}^{-1}$ for the initial 5 minutes and $40 \mathrm{mU} \cdot \mathrm{m}^{-2} \mathrm{BSA} \cdot \mathrm{min}^{-1}$ for an additional 5 minutes). 
Table 1 Subjects' anthropometric and basic metabolic characteristics at the time of screening

\begin{tabular}{|c|c|c|c|c|c|c|c|}
\hline & \multicolumn{2}{|c|}{ MEN } & \multicolumn{2}{|c|}{ WOMEN } & \multicolumn{3}{|c|}{ ANOVA } \\
\hline & Young & Old & Young & Old & Sex & Age & Interaction \\
\hline Age (years) & $40 \pm 2$ & $69 \pm 1$ & $37 \pm 2$ & $73 \pm 2$ & 0.84 & $<0.001$ & 0.10 \\
\hline Body mass (kg) & $81 \pm 4$ & $81 \pm 3$ & $69 \pm 2$ & $61 \pm 4$ & $<0.001$ & 0.22 & 0.25 \\
\hline Body mass index $\left(\mathrm{kg} / \mathrm{m}^{2}\right)$ & $26.5 \pm 1.0$ & $25.9 \pm 0.8$ & $25.0 \pm 0.8$ & $24.0 \pm 1.3$ & 0.09 & 0.44 & 0.84 \\
\hline Fat mass $(\mathrm{kg})$ & $18 \pm 2$ & $21 \pm 2$ & $22 \pm 1$ & $23 \pm 3$ & 0.16 & 0.34 & 0.61 \\
\hline Fat mass (\% body mass) & $21 \pm 2$ & $25 \pm 2$ & $32 \pm 1$ & $36 \pm 2$ & $<0.001$ & 0.055 & 0.97 \\
\hline Fat free mass $(\mathrm{kg})$ & $63 \pm 2$ & $60 \pm 2$ & $47 \pm 2$ & $38 \pm 1$ & $<0.001$ & 0.002 & 0.17 \\
\hline Fat free mass (\% body mass) & $79 \pm 2$ & $75 \pm 2$ & $68 \pm 1$ & $64 \pm 2$ & $<0.001$ & 0.055 & 0.97 \\
\hline Appendicular muscle mass (kg) & $27.5 \pm 1.1$ & $24.9 \pm 0.7$ & $18.0 \pm 0.9$ & $14.1 \pm 0.5$ & $<0.001$ & $<0.001$ & 0.46 \\
\hline Appendicular muscle mass index $\left(\mathrm{kg} / \mathrm{m}^{2}\right)$ & $9.0 \pm 0.2$ & $8.0 \pm 0.2$ & $6.5 \pm 0.2$ & $5.5 \pm 0.2$ & $<0.001$ & $<0.001$ & 0.99 \\
\hline Fasting plasma glucose (mg/dl) & $93 \pm 1$ & $95 \pm 3$ & $87 \pm 1$ & $90 \pm 1$ & 0.005 & 0.18 & 0.54 \\
\hline $2 \mathrm{~h}$ post OGTT plasma glucose $(\mathrm{mg} / \mathrm{dl})$ & $94 \pm 7$ & $111 \pm 8$ & $93 \pm 4$ & $106 \pm 7$ & 0.66 & 0.03 & 0.77 \\
\hline HOMA-IR & $1.46 \pm 0.32$ & $1.59 \pm 0.27$ & $1.08 \pm 0.22$ & $1.16 \pm 0.23$ & 0.13 & 0.69 & 0.91 \\
\hline Systolic blood pressure $(\mathrm{mm} \mathrm{Hg})$ & $109 \pm 3$ & $119 \pm 5$ & $105 \pm 3$ & $126 \pm 6$ & 0.69 & $<0.001$ & 0.21 \\
\hline Diastolic blood pressure (mm Hg) & $69 \pm 2$ & $74 \pm 3$ & $65 \pm 3$ & $68 \pm 4$ & 0.14 & 0.21 & 0.70 \\
\hline Plasma triglycerides (mg/dl) & $88 \pm 18$ & $102 \pm 12$ & $66 \pm 8$ & $72 \pm 13$ & 0.04 & 0.43 & 0.75 \\
\hline Total plasma cholesterol (mg/dl) & $170 \pm 10$ & $193 \pm 7$ & $172 \pm 8$ & $197 \pm 8$ & 0.74 & 0.01 & 0.89 \\
\hline LDL-cholesterol (mg/dl) & $106 \pm 9$ & $125 \pm 6$ & $97 \pm 7$ & $109 \pm 8$ & 0.09 & 0.03 & 0.61 \\
\hline HDL-cholesterol (mg/dl) & $47 \pm 4$ & $49 \pm 3$ & $62 \pm 4$ & $73 \pm 4$ & $<0.001$ & 0.09 & 0.25 \\
\hline Testosterone (ng/ml) & $4.8 \pm 0.5$ & $5.7 \pm 0.5$ & $0.9 \pm 0.1$ & $0.8 \pm 0.1$ & $<0.001$ & 0.26 & 0.18 \\
\hline Estradiol (pg/ml) & $25 \pm 2$ & $18 \pm 2$ & $62 \pm 9^{a}$ & $8 \pm 3^{b}$ & 0.01 & $<0.001$ & $<0.001$ \\
\hline Progesterone (ng/ml) & $0.24 \pm 0.10$ & $0.28 \pm 0.08$ & $5.08 \pm 1.53^{\mathrm{a}}$ & $0.23 \pm 0.07$ & $<0.01$ & $<0.01$ & $<0.01$ \\
\hline
\end{tabular}

Values are means \pm SEM. HOMA-IR: Homeostasis model assessment of insulin resistance. OGTT: oral glucose tolerance test.

a Value significantly different from values in men and old women $(P<0.01)$.

${ }^{\mathrm{b}}$ Value significantly different from values in men $(P<0.05)$.

Plasma amino acid availability was increased by providing an intravenous amino acid mixture (Travasol 10\%, Baxter, Deerfield, IL) infused at a rate of $105 \mathrm{mg}$ amino acids $\mathrm{kg}$ $\mathrm{FFM}^{-1} \cdot \mathrm{h}^{-1}$ (priming dose: $35 \mathrm{mg}$ amino acids.kg FFM ${ }^{-1}$ ). During the insulin infusion, euglycemia at a blood glucose concentration of $\sim 5.5 \mathrm{mM}$ was maintained by variable rate infusion of $20 \%$ dextrose solution (Baxter, Deerfield, IL) which was enriched $(2.5 \%)$ with $\left[6,6-{ }^{2} \mathrm{H}_{2}\right]$ glucose. To adjust for the increased plasma amino acid availability and reduced hepatic glucose production during the clamp procedure, the [ring $\left.{ }_{-}^{2} \mathrm{H}_{5}\right]$ phenylalanine and $\left[6,6{ }^{2} \mathrm{H}_{2}\right]$ glucose infusion rates were increased to $0.12 \mu \mathrm{mol} \cdot \mathrm{kg} \mathrm{FFM}^{-1} \cdot \mathrm{min}^{-1}$ (phenylalanine) and decreased to $0.11 \mu \mathrm{mol} \cdot \mathrm{kg}$ body $\mathrm{wt}^{-1} \min ^{-1}$ (glucose), respectively.

Blood samples ( $3 \mathrm{ml}$ each) were obtained before beginning the tracer infusion and at 60, 90, 180, 210, 220, 230, 240, 270, 300, 330, 360, 390, 400, 410, and $420 \mathrm{~min}$ to determine phenylalanine and glucose tracer-to-tracee ratios (TTR) in plasma and plasma concentrations of insulin, glucose, myostatin, follistatin, phenylalanine, and leucine (thought to be a major regulator of muscle protein synthesis [32]). Additional blood samples ( 1 ml each) were obtained every 10 minutes during the clamp procedure to monitor plasma glucose concentration. Muscle tissue ( $50-100 \mathrm{mg})$ was obtained under local anesthesia (lidocaine, $2 \%$ ) from the quadriceps femoris by using a Tilley-Henkel forceps [33] at $1 \mathrm{~h}, 4 \mathrm{~h}$ and $7 \mathrm{~h}$ after starting the tracer infusion to determine the muscle protein fractional synthesis rate (FSR) during basal conditions $(1 \mathrm{~h}-4 \mathrm{~h})$ and during the hyperinsulinemichyperaminoacidemic-euglycemic clamp $(4 \mathrm{~h}-7 \mathrm{~h})$ and the mRNA expressions (initial biopsy at $1 \mathrm{~h}$ only) of myostatin, myoD, and follistatin.

\section{Sample processing and analyses}

To determine plasma glucose concentration, blood was collected in pre-chilled tubes containing heparin, plasma was separated immediately by centrifugation and glucose concentration was measured immediately. All other blood samples were collected in pre-chilled tubes containing EDTA, plasma was separated by centrifugation within $30 \mathrm{~min}$ of collection and then stored at $-80^{\circ} \mathrm{C}$ until final analyses. Muscle samples were rinsed in icecold saline immediately after collection, cleared of visible fat and connective tissue, frozen in liquid nitrogen and stored at $-80^{\circ} \mathrm{C}$ until final analyses were performed. 
Plasma glucose concentration was measured on an automated glucose analyzer (Yellow Spring Instruments, Yellow Springs, OH). Plasma insulin concentration was determined by radioimmunoassay (Linco Research, St. Louis, MO). Commercially available ELISA kits were used to determine the concentrations of testosterone, estradiol, progesterone (all IBL America, Minneapolis, MN), myostatin (ALPCO Diagnostics, Salem, NH) and follistatin (R\&D Systems, Minneapolis, MN) in plasma.

To determine the labeling of plasma glucose, plasma proteins were precipitated with ice-cold acetone, and lipids were extracted with hexane. The aqueous phase, containing glucose, was dried by speed-vac centrifugation (Savant Instruments, Farmingdale, NY), glucose was derivatized with heptafluorobutyric acid and the TTR was determined by using gas-chromatography/massspectrometry (GC-MS, Hewlett-Packard MSD 5973 system with capillary column) as previously described [34].

To determine plasma concentrations of leucine and phenylalanine and the labeling of plasma phenylalanine, known amounts of nor-leucine and $\left[1-{ }^{13} \mathrm{C}\right]$ phenylalanine were added to an aliquot of each plasma sample, plasma proteins were precipitated, and the supernatant, containing free amino acids, was collected to prepare the $t$-butyldimethylsilyl ( $t$-BDMS) derivative of leucine and phenylalanine to determine their TTRs by GC-MS (MSD 5973 System, Hewlett-Packard) [35,36]. To determine phenylalanine labeling in muscle proteins and in tissue fluid, samples $(\sim 20 \mathrm{mg})$ were homogenized in $1 \mathrm{ml}$ trichloroacetic acid solution $(3 \% \mathrm{w} / \mathrm{v})$, proteins were precipitated by centrifugation, and the supernatant, containing free amino acids, was collected. The pellet containing muscle proteins was washed and then hydrolyzed in $6 \mathrm{~N} \mathrm{HCl}$ at $110^{\circ} \mathrm{C}$ for $24 \mathrm{~h}$. Amino acids in the protein hydrolysate and supernatant samples were purified on cation-exchange columns (Dowex $50 \mathrm{~W}$-X8200, Bio-Rad Laboratories, Richmond, CA), and the tBDMS derivative of phenylalanine prepared to determine its TTR by GC-MS (MSD 5973 System, Hewlett-Packard ) analysis [35,36]. The extent of phenylalanine labeling in plasma (from arterialized blood samples), muscle tissue fluid, and muscle protein were calculated based on the simultaneously measured TTR of standards of known isotope labeling.

Muscle myostatin, myoD and follistatin gene expression was evaluated by using RT-PCR. RNA was isolated in RNA-Bee reagent (Tel-Test, Inc, Friendswood, TX), quantified spectrophotometrically (NanoDrop 1000, Thermo Scientific, Waltham, MA) and reverse transcribed (Taqman Reverse Transcription Kit, Applied Biosystems, Foster City, CA) by using the SYBR Green Master Mix (Applied Biosystems, Carlsbad, CA) on an ABI 7500 real-time PCR system (Applied Biosystems, Carlsbad, CA) using the following primer sequences (all
5 'to 3 '). Myostatin forward: ACC TGT TTA TGC TGA TTG TTG CT, reverse: GAG CTG TTT CCA GAC GAA GTT TA. MyoD forward: CGC CAT CCG CTA TAT CGA GG, reverse: CTG TAG TCC ATC ATG CCG TCG. Follistatin forward: GTA ATC GGA TTT GCC CAG AGC, reverse: GCA GGC AGG TAG CCT TTC T. Results were normalized to the 36B4 housekeeping gene.

\section{Calculations}

The muscle protein FSR was calculated from the rate of [ring- ${ }^{2} \mathrm{H}_{5}$ ] phenylalanine incorporation into muscle protein, using a standard precursor-product model as follows: $\mathrm{FSR}=\Delta \mathrm{E}_{\mathrm{p}} / \mathrm{E}_{\mathrm{ic}} \times 1 / t \times 100$; where $\Delta \mathrm{E}_{\mathrm{p}}$ is the change between two consecutive biopsies in extent of labeling (TTR) of protein-bound phenylalanine. $E_{i c}$ is the mean labeling over time of the precursor for protein synthesis and $t$ is the time between biopsies. The free phenylalanine labeling in muscle tissue fluid was chosen to represent the immediate precursor for muscle protein synthesis (i.e., aminoacyl-t-RNA) [37].

Glucose rates of appearance (Ra) in plasma during basal conditions and during the clamp procedure were calculated by dividing the glucose tracer infusion rate by the average plasma (from arterialized blood samples) glucose TTR during the last $30 \mathrm{~min}$ of the basal period and the last $30 \mathrm{~min}$ of the clamp, respectively. Glucose $\mathrm{Ra}$ during basal conditions represents endogenous glucose $\mathrm{Ra}$ and thus an index of hepatic glucose production rate. During the clamp procedure, glucose Ra represents the sum of endogenous glucose $\mathrm{Ra}$ and the rate of infused glucose. Endogenous glucose $\mathrm{Ra}$ during the clamp was therefore calculated by subtracting the glucose infusion rate from glucose $\mathrm{Ra}$; glucose rate of disappearance ( $\mathrm{Rd}$ ) was assumed to be equal to glucose $\mathrm{Ra}$ plus the tracer infusion rate. The homeostasis model assessment of insulin resistance (HOMA-IR) score was calculated by dividing the product of basal glucose and insulin concentrations (expressed in $\mathrm{mM}$ and $\mathrm{mIU} / \mathrm{l}$, respectively) by 22.5 [38].

\section{Statistical analysis}

All data sets were normally distributed. Two-way analysis of variance (ANOVA; with age and study condition, i.e., basal vs. clamp as factors) was used to compare the muscle protein FSR, and substrate and hormone concentrations in young and old men and in young and old women, respectively. In addition, 2-way ANOVA with age and sex as factors was used to compare the basal muscle protein FSR, the anabolic response to increased amino acid and insulin availability, plasma substrate, hormone and myogenic regulatory factor concentrations, and muscle gene expression amongst all four groups (young men, old men, young women, and old women). 
When significant interactions were found, Tukey's post-hoc procedure was used to locate the differences. A $P$-value of $\leq 0.05$ was considered statistically significant. Data are presented as means \pm SEM unless otherwise noted (i.e., Figure 1). Statistical analyses were carried out by using the PASW statistical software package 18 (IBM, Armonk, NY).

\section{Results}

Plasma hormone, glucose and amino acid concentrations

Plasma testosterone concentration was significantly greater in men than women $(\mathrm{P}<0.001)$ and was not affected by aging (Table 1). Plasma progesterone concentration was significantly lower in men and old women than in young women $(\mathrm{P}<0.01)$. Plasma estradiol concentration was greatest in young women $(\mathrm{P}<0.01 \mathrm{com}-$ pared with all other groups) and lowest in old women $(\mathrm{P}<0.01$ vs. young and old men and young women $)$ (Table 1).

Aging had no effect on plasma glucose, insulin, leucine and phenylalanine concentrations - neither during basal, postabsorptive conditions nor during combined insulin,

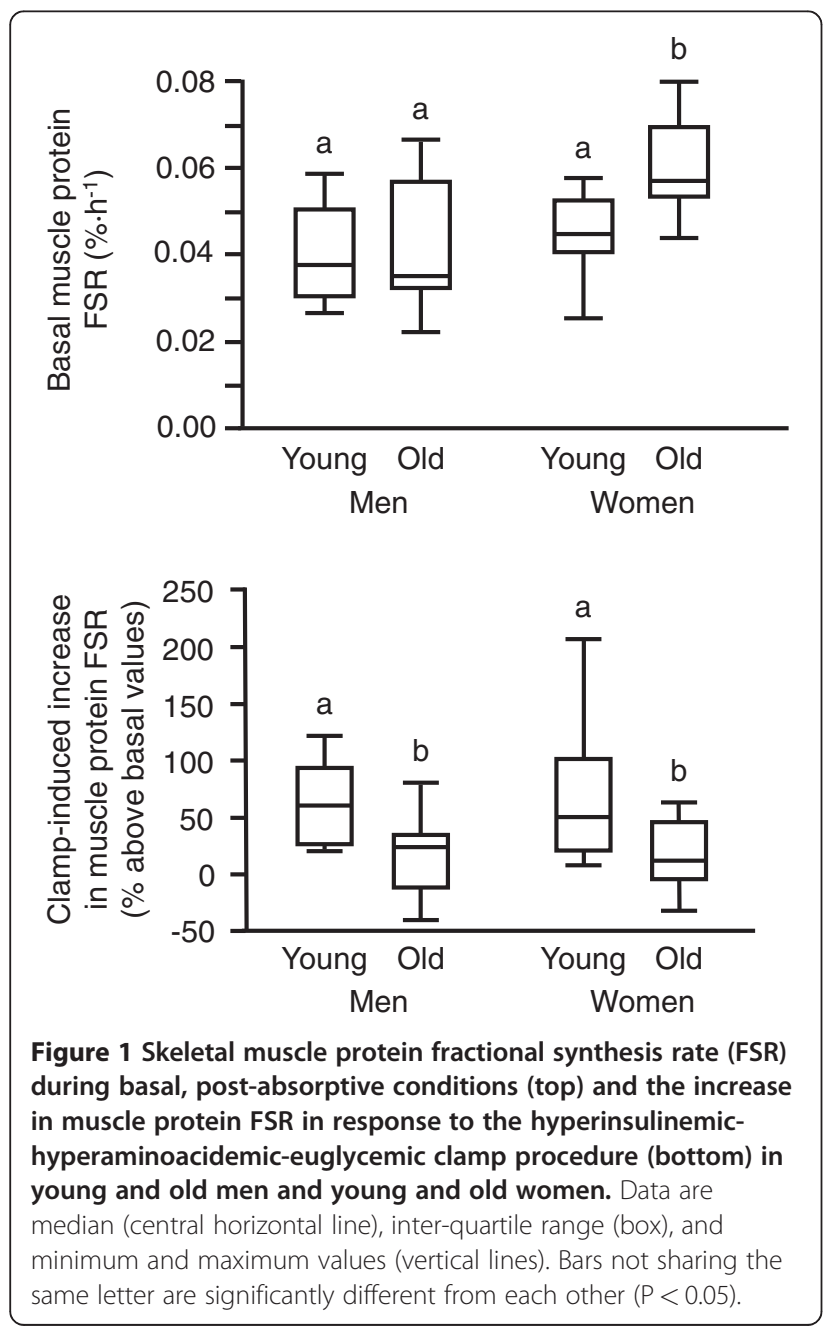

glucose and amino acid infusion (Tables 2, 3 and 4). Plasma glucose, insulin and phenylalanine concentrations were not different between men and women but plasma leucine concentration was $\sim 15 \%$ ( $\mathrm{P}<0.01)$ greater in men than in women (Tables 2, 3 and 4).

\section{Plasma myostatin and follistatin concentrations and} muscle myoD, myostatin and follistatin gene expression Plasma myostatin concentration was not different in men and women and was not affected by aging (Table 5). Plasma follistatin concentration was $\sim 30 \%$ greater in old compared with young subjects but was not significantly different in men and women (Table 5). Muscle myoD, myostatin, and follistatin mRNA expressions were not affected by age or sex (Table 5).

\section{Muscle protein synthesis}

The basal, postabsorptive muscle protein FSR was not different in young and old men and young women $\left(0.040 \pm 0.004,0.043 \pm 0.005\right.$, and $0.046 \pm 0.004 \% \cdot h^{-1}$, respectively) but was $\sim 30 \%$ greater in old women $\left(0.060 \pm 0.003 \% \cdot \mathrm{h}^{-1}\right)$ than in young and old men and young women (Figure 1, top panel and Figure 2; $\mathrm{P}<0.05$ ). Combined insulin, glucose and amino acid infusion significantly increased the muscle protein FSR both in young and old men but the increase was $\sim 60 \%$ less in the old men $(\mathrm{P}<0.05)$; consequently, the muscle protein FSR during the clamp was significantly greater $(\mathrm{P}<0.01)$ in young than in old men (Figure 2, top panel). Combined insulin, glucose and amino acid infusion also significantly increased the muscle protein FSR in young $(\mathrm{P}<0.01)$ but

Table 2 Plasma glucose, insulin, leucine and phenylalanine concentrations during basal, postabsorptive conditions and during the hyperinsulinemic-hyperaminoacidemic-euglycemic clamp procedure

\begin{tabular}{lccccc}
\hline & \multicolumn{2}{c}{ Young } & & \multicolumn{2}{c}{ Old } \\
\cline { 2 - 3 } & Basal & Clamp & & Basal & Clamp \\
\hline MEN & & & & \\
Glucose $(\mathrm{mM})$ & $5.0 \pm 0.1$ & $5.4 \pm 0.1^{\mathrm{a}}$ & & $5.1 \pm 0.1$ & $5.4 \pm 0.1^{\mathrm{a}}$ \\
Insulin $\left(\mathrm{mU} \cdot \mathrm{I}^{-1}\right)$ & $6.5 \pm 1.4$ & $29.1 \pm 2.0^{\mathrm{a}}$ & & $7.1 \pm 1.2$ & $31.3 \pm 3.2^{\mathrm{a}}$ \\
Leucine $(\mu \mathrm{M})$ & $123 \pm 7$ & $166 \pm 12^{\mathrm{a}}$ & & $118 \pm 7$ & $176 \pm 10^{\mathrm{a}}$ \\
Phenylalanine $(\mu \mathrm{M})$ & $56 \pm 7$ & $98 \pm 12^{\mathrm{a}}$ & & $64 \pm 8$ & $111 \pm 12^{\mathrm{a}}$ \\
WOMEN & & & & \\
Glucose $(\mathrm{mM})$ & $4.8 \pm 0.1$ & $5.4 \pm 0.1^{\mathrm{a}}$ & & $4.9 \pm 0.1$ & $5.5 \pm 0.1^{\mathrm{a}}$ \\
Insulin $\left(\mathrm{mU} \cdot \mathrm{I}^{-1}\right)$ & $5.2 \pm 1.2$ & $32.3 \pm 5.9^{\mathrm{a}}$ & & $5.2 \pm 1.0$ & $32.3 \pm 2.2^{\mathrm{a}}$ \\
Leucine $(\mu \mathrm{M})$ & $99 \pm 7^{\mathrm{b}}$ & $131 \pm 12^{\mathrm{a}, \mathrm{b}}$ & & $104 \pm 5^{\mathrm{b}}$ & $137 \pm 9^{\mathrm{a}, \mathrm{b}}$ \\
Phenylalanine $(\mu \mathrm{M})$ & $61 \pm 3$ & $119 \pm 10^{\mathrm{a}}$ & & $61 \pm 3$ & $109 \pm 4^{\mathrm{a}}$ \\
\hline Values ar mannnnnnn
\end{tabular}

Values are mean \pm SEM.

${ }^{a}$ Value significantly different from corresponding value during basal conditions $(P<0.001)$.

${ }^{\mathrm{b}}$ Value significantly different from corresponding value in men $(P<0.01)$. 
Table 3 Plasma phenylalanine concentrations and enrichments and muscle free and protein-bound phenylalanine enrichments during basal, postabsorptive conditions and during the hyperinsulinemic-hyperaminoacidemic clamp in young and old men

\begin{tabular}{|c|c|c|c|c|c|c|c|c|}
\hline \multirow[t]{3}{*}{ Time (min) } & \multirow{2}{*}{\multicolumn{2}{|c|}{$\begin{array}{c}\text { Concentration } \\
(\mu \mathrm{M})\end{array}$}} & \multicolumn{6}{|c|}{ Enrichment } \\
\hline & & & \multicolumn{2}{|c|}{ Muscle protein bound TTR } & \multicolumn{2}{|c|}{ Muscle free TTR } & \multicolumn{2}{|c|}{ Plasma TTR } \\
\hline & Young & Old & Young & Old & Young & Old & Young & Old \\
\hline \multicolumn{9}{|c|}{ Basal conditions } \\
\hline 60 & $59 \pm 8$ & $64 \pm 9$ & $0.000033 \pm 0.000007$ & $0.000101 \pm 0.000026$ & $0.0488 \pm 0.0037$ & $0.0545 \pm 0.0044$ & $0.0921 \pm 0.0055$ & $0.0929 \pm 0.0066$ \\
\hline 90 & $48 \pm 6$ & $67 \pm 8$ & - & - & - & - & $0.1030 \pm 0.0077$ & $0.0993 \pm 0.0090$ \\
\hline 120 & $58 \pm 9$ & $63 \pm 8$ & - & - & - & - & $0.1032 \pm 0.0056$ & $0.1119 \pm 0.0093$ \\
\hline 150 & $53 \pm 9$ & $61 \pm 9$ & - & - & - & - & $0.1118 \pm 0.0119$ & $0.1130 \pm 0.0067$ \\
\hline 180 & $56 \pm 10$ & $63 \pm 9$ & - & - & - & - & $0.1088 \pm 0.0034$ & $0.1129 \pm 0.0056$ \\
\hline 210 & $60 \pm 7$ & $66 \pm 8$ & - & - & - & - & $0.1093 \pm 0.0031$ & $0.1155 \pm 0.0078$ \\
\hline 240 & $59 \pm 8$ & $64 \pm 9$ & $0.000099 \pm 0.000009$ & $0.000186 \pm 0.000029$ & $0.0589 \pm 0.0027$ & $0.0686 \pm 0.0048$ & $0.1065 \pm 0.0032$ & $0.1194 \pm 0.0079$ \\
\hline \multicolumn{3}{|c|}{$\Delta(240-60 \mathrm{~min})$} & $0.000067 \pm 0.000009$ & $0.000085 \pm 0.000013$ & & & & \\
\hline Mean & $56 \pm 7$ & $64 \pm 8$ & & & $0.0539 \pm 0.0028$ & $0.0615 \pm 0.0041$ & $0.1050 \pm 0.0051$ & $0.1093 \pm 0.0071$ \\
\hline \multicolumn{9}{|c|}{ Hyperinsulinemic-hyperaminoacidemic clamp } \\
\hline 270 & $93 \pm 14$ & $97 \pm 10$ & - & - & - & - & $0.0969 \pm 0.0031$ & $0.1108 \pm 0.0045$ \\
\hline 300 & $88 \pm 12$ & $97 \pm 10$ & - & - & - & - & $0.0958 \pm 0.0034$ & $0.1028 \pm 0.0042$ \\
\hline 330 & $116 \pm 18$ & $107 \pm 14$ & - & - & - & - & $0.0942 \pm 0.0022$ & $0.1005 \pm 0.0050$ \\
\hline 360 & $85 \pm 10$ & $121 \pm 14$ & - & - & - & - & $0.0950 \pm 0.0025$ & $0.1000 \pm 0.0044$ \\
\hline 390 & $98 \pm 12$ & $128 \pm 16$ & - & - & - & - & $0.0937 \pm 0.0013$ & $0.1021 \pm 0.0055$ \\
\hline 420 & $108 \pm 14$ & $116 \pm 17$ & $0.000235 \pm 0.000023$ & $0.000310 \pm 0.000038$ & $0.0719 \pm 0.0030$ & $0.0806 \pm 0.0033$ & $0.0960 \pm 0.0019$ & $0.0952 \pm 0.0055$ \\
\hline \multicolumn{3}{|c|}{$\Delta(420-240 \mathrm{~min})$} & $0.000136 \pm 0.000015$ & $0.000124 \pm 0.000020$ & & & & \\
\hline Mean & $98 \pm 12$ & $111 \pm 12$ & & & $0.0654 \pm 0.0027$ & $0.0746 \pm 0.0038$ & $0.0953 \pm 0.0021$ & $0.1019 \pm 0.0043$ \\
\hline
\end{tabular}

Values are means \pm SEM.

not in old women; consequently, the muscle protein FSR during the clamp was not different between young and old women (Figure 2, bottom panel). Overall, the anabolic response (increase in muscle protein FSR above basal values) was greater in young than old subjects but was not different in young men and young women and not different in old men and old women (Figure 1, bottom panel).

\section{Glucose kinetics}

Basal glucose Ra was not different in young and old subjects but was significantly lower in men compared with women $\left(9.4 \pm 0.3\right.$ and $9.6 \pm 0.3 \mu \mathrm{mol} \cdot \mathrm{kg}$ body $\mathrm{wt}^{-1} \cdot \mathrm{min}^{-1}$ in young and old men; $9.9 \pm 0.4$ and $11.3 \pm 0.6 \mu \mathrm{mol} \cdot \mathrm{kg}$ body $\mathrm{wt}^{-1} \cdot \mathrm{min}^{-1}$ in young and old women; main effect of sex; $\mathrm{P}<0.05)$. During the clamp, glucose Ra decreased $(\mathrm{P}<0.01)$ to the same extent in all groups (i.e., by $71 \pm 3$, $70 \pm 4,73 \pm 5$, and $68 \pm 6 \%$ in young and old men, and young and old women, respectively). The insulin mediated increase in glucose $\mathrm{Rd}$ during the clamp $(144 \pm 17,133 \pm 23,168 \pm 18$ and $145 \pm 22 \%$ in young and old men and young and old women, respectively) was also not affected by age $(P=0.44)$ or sex $(P=0.40)$.

\section{Discussion}

Nutritional stimuli (amino acids and insulin) along with physical activity are the major acute physiological regulators of muscle protein turnover and are responsible for its diurnal oscillations and overall muscle protein net balance [39]. In the present study, we examined how aging in men and women affects the rate of muscle protein synthesis during basal, postabsorptive conditions and during a hyperaminoacidemic-hyperinsulinemiceuglycemic clamp. We discovered that both old men and old women exhibit anabolic resistance to nutritional stimuli; in addition, the basal rate of muscle protein synthesis is increased in old women compared with young women and young and old men. Aging therefore affects muscle protein synthesis differently in men and women, and men and women need to be considered separately when evaluating the effect of aging on muscle protein synthesis.

Only a limited number of studies have been conducted to investigate potential sexual dimorphism in muscle protein turnover to date. Most of them were limited to young men and women only and found, as we did in the present study, no differences in muscle protein turnover 
Table 4 Plasma phenylalanine concentrations and enrichments and muscle free and protein-bound phenylalanine enrichments during basal, postabsorptive conditions and during the hyperinsulinemic-hyperaminoacidemic clamp in young and old women

\begin{tabular}{|c|c|c|c|c|c|c|c|c|}
\hline \multirow[t]{3}{*}{ Time (min) } & \multirow{2}{*}{\multicolumn{2}{|c|}{$\begin{array}{c}\text { Concentration } \\
(\mu \mathrm{M})\end{array}$}} & \multicolumn{6}{|c|}{ Enrichment } \\
\hline & & & \multicolumn{2}{|c|}{ Muscle protein bound TTR } & \multicolumn{2}{|c|}{ Muscle free TTR } & \multicolumn{2}{|c|}{ Plasma TTR } \\
\hline & Young & Old & Young & Old & Young & Old & Young & Old \\
\hline \multicolumn{9}{|c|}{ Basal conditions } \\
\hline 60 & $63 \pm 3$ & $60 \pm 3$ & $0.000057 \pm 0.000015$ & $0.000062 \pm 0.000017$ & $0.0602 \pm 0.0032$ & $0.0622 \pm 0.0052$ & $0.0906 \pm 0.0038$ & $0.0862 \pm 0.0027$ \\
\hline 90 & $64 \pm 6$ & $61 \pm 2$ & - & - & - & - & $0.0986 \pm 0.0048$ & $0.0893 \pm 0.0039$ \\
\hline 120 & $56 \pm 3$ & $54 \pm 2$ & - & - & - & - & $0.1009 \pm 0.0015$ & $0.0952 \pm 0.0040$ \\
\hline 150 & $56 \pm 5$ & $64 \pm 3$ & - & - & - & - & $0.0998 \pm 0.0031$ & $0.0967 \pm 0.0043$ \\
\hline 180 & $59 \pm 2$ & $60 \pm 4$ & - & - & - & - & $0.1038 \pm 0.0034$ & $0.1013 \pm 0.0038$ \\
\hline 210 & $63 \pm 3$ & $62 \pm 4$ & - & - & - & - & $0.1041 \pm 0.0029$ & $0.1020 \pm 0.0043$ \\
\hline 240 & $66 \pm 2$ & $65 \pm 4$ & $0.000147 \pm 0.000015$ & $0.000176 \pm 0.000020$ & $0.0722 \pm 0.0040$ & $0.0673 \pm 0.0045$ & $0.1023 \pm 0.0024$ & $0.1026 \pm 0.0039$ \\
\hline \multicolumn{3}{|c|}{$\Delta(240-60 \mathrm{~min})$} & $0.000090 \pm 0.000014$ & $0.000114 \pm 0.000012$ & & & & \\
\hline Mean & $61 \pm 3$ & $61 \pm 3$ & & & $0.0662 \pm 0.0035$ & $0.0648 \pm 0.0044$ & $0.1000 \pm 0.0027$ & $0.0962 \pm 0.0035$ \\
\hline \multicolumn{9}{|c|}{ Hyperinsulinemic-hyperaminoacidemic clamp } \\
\hline 270 & $111 \pm 10$ & $92 \pm 4$ & - & - & - & - & $0.1027 \pm 0.0045$ & $0.1013 \pm 0.0086$ \\
\hline 300 & $108 \pm 8$ & $111 \pm 7$ & - & - & - & - & $0.0950 \pm 0.0024$ & $0.1026 \pm 0.0065$ \\
\hline 330 & $122 \pm 16$ & $106 \pm 7$ & - & - & - & - & $0.0926 \pm 0.0020$ & $0.0894 \pm 0.0069$ \\
\hline 360 & $124 \pm 14$ & $122 \pm 9$ & - & - & - & - & $0.0944 \pm 0.0032$ & $0.0922 \pm 0.0035$ \\
\hline 390 & $128 \pm 11$ & $109 \pm 5$ & - & - & - & - & $0.0970 \pm 0.0029$ & $0.0838 \pm 0.0063$ \\
\hline 420 & $120 \pm 5$ & $114 \pm 3$ & $0.000305 \pm 0.000020$ & $0.000348 \pm 0.000027$ & $0.0752 \pm 0.0019$ & $0.0782 \pm 0.0033$ & $0.0971 \pm 0.0026$ & $0.0929 \pm 0.0038$ \\
\hline \multicolumn{3}{|c|}{$\Delta(420-240 \mathrm{~min})$} & $0.000157 \pm 0.000016$ & $0.000171 \pm 0.000017$ & & & & \\
\hline Mean & $119 \pm 10$ & $109 \pm 4$ & & & $0.0737 \pm 0.0028$ & $0.0727 \pm 0.0034$ & $0.0965 \pm 0.0024$ & $0.0937 \pm 0.0046$ \\
\hline
\end{tabular}

Values are means \pm SEM.

between them [7-11]. In another study we conducted, we found major differences in muscle protein synthesis rates between old men and women [12]; however, the fact that subjects in this study were obese has been criticized as a major confounding variable. Only one study so far evaluated the effect of both sex and age on muscle protein turnover [13] and found no age by sex interaction in the basal rate of muscle protein synthesis. However, this study [13] was limited to basal, postabsorptive conditions only and included only old men with hypogonadism and old women with low serum dehydroepiandrosterone concentration, which may have confounded the results. Hypoandrogenemia is associated with a reduced lean body mass [14] and treatment with testosterone increases the muscle protein synthesis rate [15-20]. In the present study, plasma androgen concentrations were within the normal range for all subjects.

Consistent with the results from many earlier studies which focused on the effect of aging but included only men or both men and women without analyzing them

Table 5 Plasma follistatin and myostatin concentrations and muscle myoD, myostatin, and follistatin gene expression in young and old men and women

\begin{tabular}{|c|c|c|c|c|c|c|c|}
\hline & \multicolumn{2}{|c|}{ MEN } & \multicolumn{2}{|c|}{ WOMEN } & \multicolumn{3}{|c|}{ ANOVA } \\
\hline & Young & Old & Young & Old & Sex & Age & Interaction \\
\hline \multicolumn{8}{|c|}{ Plasma (ng/mL) } \\
\hline Myostatin & $3.12 \pm 0.30$ & $3.36 \pm 0.24$ & $3.29 \pm 0.34$ & $3.54 \pm 0.42$ & 0.61 & 0.47 & 0.99 \\
\hline Follistatin & $1.58 \pm 0.12$ & $1.87 \pm 0.12$ & $1.22 \pm 0.08$ & $1.81 \pm 0.12$ & 0.07 & 0.005 & 0.19 \\
\hline \multicolumn{8}{|c|}{ Muscle mRNA (arbitrary units) } \\
\hline Myostatin & $1.00 \pm 0.28$ & $0.73 \pm 0.17$ & $0.82 \pm 0.12$ & $0.95 \pm 0.17$ & 0.92 & 0.70 & 0.28 \\
\hline Follistatin & $1.00 \pm 0.32$ & $0.68 \pm 0.19$ & $1.40 \pm 0.46$ & $1.55 \pm 0.59$ & 0.15 & 0.85 & 0.58 \\
\hline MyoD & $1.00 \pm 0.39$ & $1.21 \pm 0.21$ & $1.26 \pm 0.38$ & $1.12 \pm 0.28$ & 0.68 & 0.97 & 0.68 \\
\hline
\end{tabular}

Values are means \pm SEM. Muscle mRNA data were obtained from muscle biopsies collected during basal conditions. 


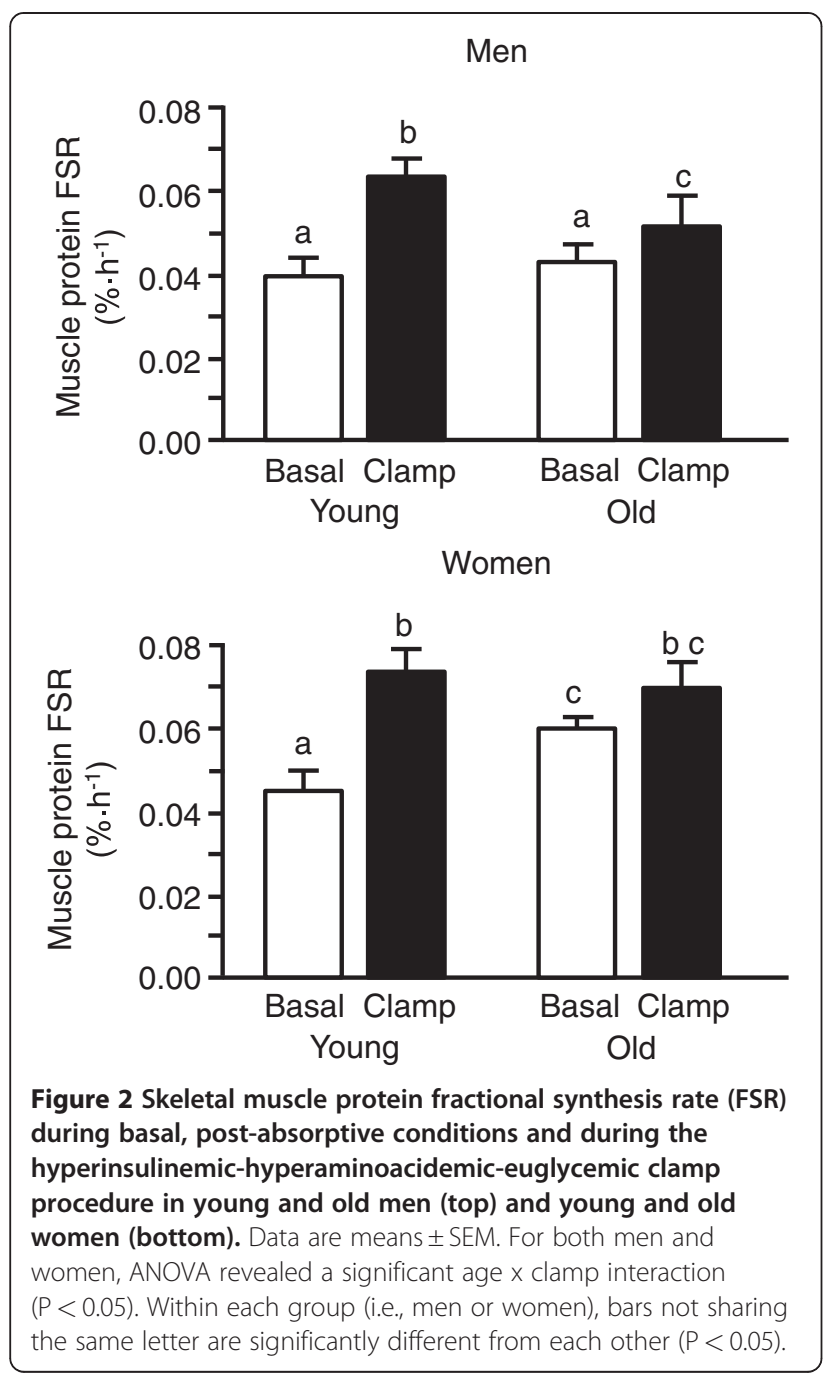

separately [30,40-47], we found no difference in the basal, postabsorptive muscle protein FSR in healthy young and old men and a blunted anabolic response to nutritional stimuli in old compared with young subjects (both men and women). The basal rate of muscle protein synthesis, however, was greater in our old compared with our young women and young and old men. This is consistent with what we have previously observed in obese older adults [12] but contradicts the only other study we are aware of that specifically evaluated the effect of aging on muscle protein synthesis in women [48]. Chevalier et al. [48] report no difference between young and old women in the basal rate of muscle protein synthesis and the muscle protein synthesis rate during a simulated fed state. The reason(s) for the discrepancy are not entirely clear but could be related to the amount of amino acids provided. Chevalier et al. [48] raised the plasma leucine concentration during the clamp to $\sim 250 \%$ above basal values, which is equivalent to the peak increase after a maximally stimulating dose of protein (30 g) [49] or amino acids [40]. The clamp in our study, on the other hand, was designed to achieve plasma insulin and amino acid concentrations equivalent to those seen after ingestion of $\sim 22 \mathrm{~g}$ of casein or soy protein or consumption of a $2300-3300 \mathrm{~kJ}$ mixed nutrient meal containing $\sim 26$ g protein and $\sim 70$ to $90 \mathrm{~g}$ carbohydrates [50-52]; plasma leucine concentration during the clamp in our study was therefore increased to only $40 \%$ above basal values. If this is indeed the main reason for the difference in results between our study and the one by Chevalier et al. [48], it would suggest that old women may require a large amount of protein to respond adequately to nutritional stimuli. Old men, on the other hand, seem to be unable to benefit from the consumption of more protein/amino acids [40]. It has also been proposed that differences in the availability of leucine per se, which is thought to be a major regulator of muscle protein synthesis [32], might be a key factor responsible for whether or not there is anabolic resistance in older adults [53]. However, plasma leucine concentration in our study was not different between young and old men and not different between young and old women and can therefore not help explain the anabolic resistance of muscle in older adults. Moreover, plasma leucine concentration was $\sim 20 \%$ lower in women (both young and old) than in men, which is consistent with earlier work from our own group [12] and by others [54] but again does not help explain the differences in muscle protein synthesis rates between groups in our study. The reason(s) for the difference in plasma leucine concentration is currently unclear.

The mechanism(s) responsible for the faster basal muscle protein FSR in our old women and why aging affects the basal muscle protein synthesis rate differently in men and women is unclear. One potential explanation may be that the menopause-induced decline in estradiol and progesterone concentrations leads to an increase in the basal rate of muscle protein synthesis. In rodents, surgically-induced menopause (ovariectomy) increases the rate of muscle protein synthesis and replacement of either estrogen or progesterone prevents this effect [55]. Whether the age-related declines in estrogens and/or progesterone similarly affect muscle protein turnover in women is not known; accordingly, it is also not known whether estrogens and/or progesterone are potentially important regulators of muscle protein metabolism in men.

In line with the muscle protein synthesis data in the present study, we have recently reported no difference in anabolic signaling between young men and young women [11] and several other investigators have reported a blunted nutrient-induced increase in mTOR signaling in old compared with young subjects $[40,42]$. In the present study, we therefore chose to focus on factors that could potentially help explain the greater basal rate of muscle protein synthesis in old women compared 
with young women and young and old men and possibly provide some insight into the anabolic resistance of older adults. To this end, we evaluated the muscle mRNA expression of the myogenic regulatory factor myoD, and the plasma concentration and muscle mRNA expression of the muscle growth inhibitor myostatin and follistatin. Myostatin is a muscle growth inhibitor which is produced primarily in skeletal muscle cells, circulates in the blood and acts on muscle tissue by blocking genes induced during differentiation (e.g., myoD [21]) and by inhibiting the anabolic signaling cascade and muscle protein synthesis [22-26]. Follistatin is ubiquitously expressed, circulates in the blood and binds to and thereby inhibits myostatin $[27,28]$. We found that plasma follistatin concentration was, paradoxically, greater in old than young subjects but not different in men and women whereas plasma myostatin concentration and muscle myoD, myostatin and follistatin mRNA expressions were not different in men and women and not affected by aging. These findings are generally consistent with those reported by others [56-59] and do not match the differences in muscle protein turnover between young and old men and women. We recognize that our muscle mRNA expression data may provide only limited information; however, in pilot experiments, we were not able to identify antibodies specific for myoD and myostatin that passed rigorous quality control criteria. The exact mechanism(s) of myostatin action (e.g., via plasma or locally within muscle or both) are not entirely clear and few studies have compared muscle and plasma myostatin concentrations. Nevertheless, those that did, show good qualitative agreement between the plasma myostatin concentration and myostatin protein expression in human muscle $[60,61]$.

The higher basal muscle protein FSR in old women is not inconsistent with a reduced muscle mass in old compared with young women because muscle mass is determined by the net balance between muscle protein synthesis and muscle protein breakdown. In fact, very high muscle protein synthesis rates are often observed in extremely catabolic conditions such as major burns because both muscle protein synthesis and muscle protein breakdown rates are upregulated but the increase in muscle protein breakdown exceeds the increase in muscle protein synthesis resulting in net muscle protein loss despite an increase in muscle protein synthesis [62]. Our data therefore suggest that accelerated muscle protein breakdown may be a major contributor to the ageassociated loss of muscle mass in older women.

We measured the global/mixed muscle protein synthesis rate and it is therefore possible, but unlikely, that our results are not applicable to myofibrillar proteins, which account for the bulk of muscle proteins. During basal, postabsorptive conditions at rest, there is very good correlation between the mixed and the myofibrillar protein
FSR in both young and older subjects [63-65]. Furthermore, the increases in myofibrillar, sarcoplasmic and mitochondrial protein synthesis rates in response to hyperaminoacidemia/hyperinsulinemia mirror each other [40,66-68].

In summary, we report that healthy aging is associated with an increase in the basal rate of muscle protein synthesis in women and resistance to the anabolic effect of nutritional stimuli in both men and women. These findings indicate that there is sexual dimorphism in the agerelated changes in muscle protein synthesis and the metabolic processes responsible for the age-related decline in muscle mass.

\section{Conclusion}

There are no differences in the rates of muscle protein synthesis in young men and young women but there is sexual dimorphism in the age-related changes in muscle protein synthesis. Men and women therefore need to be considered separately when evaluating muscle protein synthesis rates in older adults.

\section{Abbreviations \\ ANOVA: analysis of variance; BSA: body surface area; FFM: fat-free mass; FSR: fractional synthesis rate; GC-MS: gas chromatography mass spectrometry; HOMA-IR: homeostasis model assessment of insulin resistance; Ra: rate of appearance; Rd: rate of disappearance; RNA: ribonucleic acid; t-BDMS: $t$-butyldimethylsilyl; TTR: tracer-to-tracee ratio.}

\section{Competing interests}

The authors declare that they have no competing interests.

\section{Authors' contributions}

GIS carried out the experiments, processed muscle samples, analyzed the data and drafted the manuscript. DNR was responsible for the medical aspects of the study and obtained the biopsy samples. AMH, KTC, and BNF were involved in processing the study samples and interpretation of the data. BM designed the study and obtained funding for the study, supervised the experiments, sample processing and data analyses and prepared the final version of the manuscript. All authors read and approved the final manuscript.

\section{Sources of funding}

This publication was supported by NIH grants AR 49869, HD57796, DK87821, UL1 RR024992 (Washington University Clinical Translational Science Award), RR 00954 (Biomedical Mass Spectrometry Resource), and DK 56341 (Nutrition and Obesity Research Center), and a grant from the Longer Life Foundation. Kari Chambers was supported by an American Liver Foundation Liver Scholar Award and Dominic Reeds was supported by an American Society of Nutrition Physician Nutrition Support Specialist Award.

\section{Acknowledgements}

The authors wish to thank Hadia Jaffery, Rachel Burrows and the staff of the Washington University School of Medicine Research Participant Registry for help in subject recruitment, loana Gruchevska, Janine Kampelman, the staff of the Clinical Research Unit, and Dr. Adewole Okunade for technical

assistance, and the study subjects for their participation.

Received: 8 February 2012 Accepted: 6 May 2012

Published: 23 May 2012

\section{References}

1. Forbes $G B$, Reina JC: Adult lean body mass declines with age: some longitudinal observations. Metabolism 1970, 19:653-663. 
2. Lee SJ, Janssen I, Heymsfield SB, Ross R: Relation between whole-body and regional measures of human skeletal muscle. Am J Clin Nutr 2004, 80:1215-1221

3. Mingrone G, Marino S, DeGaetano A, Capristo E, Heymsfield SB, Gasbarrini G, Greco AV: Different limit to the body's ability of increasing fat-free mass. Metabolism 2001, 50:1004-1007.

4. Gallagher D, Ruts E, Visser M, Heshka S, Baumgartner RN, Wang J, Pierson RN, Pi-Sunyer FX, Heymsfield SB: Weight stability masks sarcopenia in elderly men and women. Am J Physiol Endocrinol Metab 2000, 279:E366-375.

5. Hughes VA, Frontera WR, Roubenoff R, Evans WJ, Singh MA: Longitudinal changes in body composition in older men and women: role of body weight change and physical activity. Am J Clin Nutr 2002, 76:473-481.

6. Zamboni M, Zoico E, Scartezzini T, Mazzali G, Tosoni P, Zivelonghi A, Gallagher D, De Pergola G, Di Francesco V, Bosello O: Body composition changes in stable-weight elderly subjects: the effect of sex. Aging Clin Exp Res 2003, 15:321-327.

7. Dreyer HC, Fujita S, Glynn EL, Drummond MJ, Volpi E, Rasmussen BB: Resistance exercise increases leg muscle protein synthesis and mTOR signalling independent of sex. Acta Physiol 2010, 199:71-81.

8. Fujita S, Rasmussen BB, Bell JA, Cadenas JG, Volpi E: Basal muscle intracellular amino acid kinetics in women and men. Am J Physiol Endocrinol Metab 2007, 292:E77-83.

9. Jahn LA, Barrett EJ, Genco ML, Wei L, Spraggins TA, Fryburg DA: Tissue composition affects measures of postabsorptive human skeletal muscle metabolism: comparison across genders. J Clin Endocrinol Metab 1999, 84:1007-1010.

10. Parise G, Mihic S, MacLennan D, Yarasheski KE, Tarnopolsky MA: Effects of acute creatine monohydrate supplementation on leucine kinetics and mixed-muscle protein synthesis. J Appl Physiol 2001, 91:1041-1047.

11. Smith Gl, Atherton P, Reeds DN, Mohammed BS, Jaffery H, Rankin D, Rennie MJ, Mittendorfer B: No major sex differences in muscle protein synthesis rates in the postabsorptive state and during hyperinsulinemia-hyperaminoacidemia in middle-aged adults. J Appl Physiol 2009, 107:1308-1315.

12. Smith Gl, Atherton P, Villareal DT, Frimel TN, Rankin D, Rennie MJ, Mittendorfer B: Differences in muscle protein synthesis and anabolic signaling in the postabsorptive state and in response to food in 65-80 year old men and women. PLOS ONE 2008, 3:e1875.

13. Henderson GC, Dhatariya K, Ford GC, Klaus KA, Basu R, Rizza RA, Jensen MD, Khosla S, O'Brien P, Nair KS: Higher muscle protein synthesis in women than men across the lifespan, and failure of androgen administration to amend age-related decrements. FASEB J 2009, 23:631-641.

14. Katznelson L, Finkelstein JS, Schoenfeld DA, Rosenthal DI, Anderson EJ, Klibanski A: Increase in bone density and lean body mass during testosterone administration in men with acquired hypogonadism. J Clin Endocrinol Metab 1996, 81:4358-4365.

15. Brodsky IG, Balagopal P, Nair KS: Effects of testosterone replacement on muscle mass and muscle protein synthesis in hypogonadal men-a clinical research center study. J Clin Endocrinol Metab 1996, 81:3469-3475.

16. Ferrando AA, Tipton KD, Doyle D, Phillips SM, Cortiella J, Wolfe RR: Testosterone injection stimulates net protein synthesis but not tissue amino acid transport. Am J Physiol 1998, 275:E864-871.

17. Griggs RC, Halliday D, Kingston W, Moxley RT 3rd: Effect of testosterone on muscle protein synthesis in myotonic dystrophy. Ann Neurol 1986, 20:590-596.

18. Griggs RC, Kingston W, Jozefowicz RF, Herr BE, Forbes G, Halliday D: Effect of testosterone on muscle mass and muscle protein synthesis. J Appl Physiol 1989, 66:498-503.

19. Urban RJ, Bodenburg YH, Gilkison C, Foxworth J, Coggan AR, Wolfe RR, Ferrando A: Testosterone administration to elderly men increases skeletal muscle strength and protein synthesis. Am J Physiol 1995, 269:E820-826.

20. Wang X, Smith Gl, Patterson BW, Reeds DN, Kampelman J, Magkos F, Mittendorfer B: Testosterone increases the muscle protein synthesis rate but does not affect very-low-density lipoprotein metabolism in obese premenopausal women. Am J Physiol Endocrinol Metab 2012, 302:E740-746

21. Guttridge DC: Signaling pathways weigh in on decisions to make or break skeletal muscle. Curr Opin Clin Nutr Metab Care 2004, 7:443-450.

22. Amirouche A, Durieux AC, Banzet S, Koulmann N, Bonnefoy R, Mouret C, Bigard X, Peinnequin A, Freyssenet D: Down-regulation of Akt/mammalian target of rapamycin signaling pathway in response to myostatin overexpression in skeletal muscle. Endocrinology 2009, 150:286-294.

23. Glass DJ: PI3 kinase regulation of skeletal muscle hypertrophy and atrophy. Curr Top Microbiol Immunol 2010, 346:267-278.

24. Lipina C, Kendall H, McPherron AC, Taylor PM, Hundal HS: Mechanisms involved in the enhancement of mammalian target of rapamycin signalling and hypertrophy in skeletal muscle of myostatin-deficient mice. FEBS Lett 2010, 584:2403-2408.

25. Welle S, Bhatt K, Pinkert CA: Myofibrillar protein synthesis in myostatindeficient mice. Am J Physiol Endocrinol Metab 2006, 290:E409-415.

26. Welle S, Burgess K, Mehta S: Stimulation of skeletal muscle myofibrillar protein synthesis, p70 S6 kinase phosphorylation, and ribosomal protein S6 phosphorylation by inhibition of myostatin in mature mice. Am J Physiol Endocrinol Metab 2009, 296:E567-572.

27. Haidet AM, Rizo L, Handy C, Umapathi P, Eagle A, Shilling C, Boue D, Martin PT, Sahenk Z, Mendell JR, Kaspar BK: Long-term enhancement of skeletal muscle mass and strength by single gene administration of myostatin inhibitors. Proc Natl Acad Sci U S A 2008, 105:4318-4322.

28. Lee SJ, McPherron AC: Regulation of myostatin activity and muscle growth. Proc Natl Acad Sci U S A 2001, 98:9306-9311.

29. Schaap LA, Pluijm SM, Deeg DJ, Visser M: Inflammatory markers and loss of muscle mass (sarcopenia) and strength. Am J Med 2006, 119(526):529-517.

30. Volpi E, Sheffield-Moore M, Rasmussen BB, Wolfe RR: Basal muscle amino acid kinetics and protein synthesis in healthy young and older men. JAMA 2001, 286:1206-1212.

31. Miller BF, Hansen M, Olesen JL, Flyvbjerg A, Schwarz P, Babraj JA, Smith K, Rennie MJ, Kjaer M: No effect of menstrual cycle on myofibrillar and connective tissue protein synthesis in contracting skeletal muscle. Am J Physiol Endocrinol Metab 2006, 290:E163-E168.

32. Rieu I, Balage M, Sornet C, Giraudet C, Pujos E, Grizard J, Mosoni L, Dardevet D: Leucine supplementation improves muscle protein synthesis in elderly men independently of hyperaminoacidaemia. J Physiol 2006, 575:305-315.

33. Dietrichson P, Coakley J, Smith PE, Griffiths RD, Helliwell TR, Edwards RH: Conchotome and needle percutaneous biopsy of skeletal muscle. J Neurol Neurosurg Psychiatry 1987, 50:1461-1467.

34. Mittendorfer B, Horowitz JF, Klein S: Gender differences in lipid and glucose kinetics during short-term fasting. Am J Physiol Endocrinol Metab 2001, 281:E1333-1339.

35. Patterson BW, Zhang XJ, Chen Y, Klein S, Wolfe RR: Measurement of very low stable isotope enrichments by gas chromatography/mass spectrometry: application to measurement of muscle protein synthesis. Metabolism 1997, 46:943-948.

36. Smith Gl, Villareal DT, Mittendorfer B: Measurement of human mixed muscle protein fractional synthesis rate depends on the choice of amino acid tracer. Am J Physiol Endocrinol Metab 2007, 293:E666-671.

37. Watt PW, Lindsay Y, Scrimgeour CM, Chien PA, Gibson JN, Taylor DJ, Rennie MJ: Isolation of aminoacyl-tRNA and its labeling with stable-isotope tracers: Use in studies of human tissue protein synthesis. Proc Natl Acad Sci U S A 1991, 88:5892-5896.

38. Matthews DR, Hosker JP, Rudenski AS, Naylor BA, Treacher DF, Turner RC: Homeostasis model assessment: insulin resistance and beta-cell function from fasting plasma glucose and insulin concentrations in man. Diabetologia 1985, 28:412-419.

39. Rennie MJ, Wackerhage $H$, Spangenburg EE, Booth FW: Control of the size of the human muscle mass. Annu Rev Physiol 2004, 66:799-828.

40. Cuthbertson D, Smith K, Babraj J, Leese G, Waddell T, Atherton P, Wackerhage $H$, Taylor PM, Rennie MJ: Anabolic signaling deficits underlie amino acid resistance of wasting, aging muscle. FASEB J 2005, 19:422-424.

41. Drummond MJ, Dreyer HC, Pennings B, Fry CS, Dhanani S, Dillon EL, Sheffield-Moore M, Volpi E, Rasmussen BB: Skeletal muscle protein anabolic response to resistance exercise and essential amino acids is delayed with aging. J Appl Physiol 2008, 104:1452-1461.

42. Guillet C: Prod'homme M, Balage M, Gachon P, Giraudet C, Morin L, Grizard J, Boirie Y: Impaired anabolic response of muscle protein synthesis is associated with S6K1 dysregulation in elderly humans. FASEB J 2004, 18:1586-1587.

43. Katsanos CS, Kobayashi H, Sheffield-Moore M, Aarsland A, Wolfe RR: Aging is associated with diminished accretion of muscle proteins after the 
ingestion of a small bolus of essential amino acids. Am J Clin Nutr 2005, 82:1065-1073.

44. Kumar V, Selby A, Rankin D, Patel R, Atherton P, Hildebrandt W, Williams J, Smith K, Seynnes O, Hiscock N, Rennie MJ: Age-related differences in the dose-response relationship of muscle protein synthesis to resistance exercise in young and old men. J Physiol 2009, 587:211-217.

45. Rasmussen BB, Fujita S, Wolfe RR, Mittendorfer B, Roy M, Rowe VL, Volpi E: Insulin resistance of muscle protein metabolism in aging. FASEB J 2006, 20:768-769.

46. Smith Gl, Atherton P, Reeds DN, Mohammed BS, Rankin D, Rennie MJ, Mittendorfer B: Dietary omega-3 fatty acid supplementation increases the rate of muscle protein synthesis in older adults: a randomized controlled trial. Am J Clin Nutr 2011, 93:402-412.

47. Volpi E, Mittendorfer B, Rasmussen BB, Wolfe RR: The response of muscle protein anabolism to combined hyperaminoacidemia and glucoseinduced hyperinsulinemia is impaired in the elderly. J Clin Endocrinol Metab 2000, 85:4481-4490.

48. Chevalier S, Goulet ED, Burgos SA, Wykes LJ, Morais JA: Protein anabolic responses to a fed steady state in healthy aging. J Gerontol A Biol Sci Med Sci 2011, 66:681-688.

49. Moore DR, Robinson MJ, Fry JL, Tang JE, Glover El, Wilkinson SB, Prior T, Tarnopolsky MA, Phillips SM: Ingested protein dose response of muscle and albumin protein synthesis after resistance exercise in young men. Am J Clin Nutr 2009, 89:161-168.

50. Conley TB, Apolzan JW, Leidy HJ, Greaves KA, Lim E, Campbell WW: Effect of food form on postprandial plasma amino acid concentrations in older adults. Br J Nutr 2011, 106:203-207.

51. Elia M, Folmer P, Schlatmann A, Goren A, Austin S: Carbohydrate, fat, and protein metabolism in muscle and in the whole body after mixed meal ingestion. Metabolism 1988, 37:542-551.

52. Tang JE, Moore DR, Kujbida GW, Tarnopolsky MA, Phillips SM: Ingestion of whey hydrolysate, casein, or soy protein isolate: effects on mixed muscle protein synthesis at rest and following resistance exercise in young men. J Appl Physiol 2009, 107:987-992.

53. Burd NA, Wall BT, Van Loon LJ: The curious case of anabolic resistance: old wives' tales or new fables? J Appl Physiol In Press.

54. Pitkanen HT, Oja SS, Kemppainen K, Seppa JM, Mero AA: Serum amino acid concentrations in aging men and women. Amino Acids 2003, 24:413-421.

55. Toth MJ, Poehlman ET, Matthews DE, Tchernof A, MacCoss MJ: Effects of estradiol and progesterone on body composition, protein synthesis, and lipoprotein lipase in rats. Am J Physiol Endocrinol Metab 2001, 280:E496-501

56. Drummond MJ, Miyazaki M, Dreyer HC, Pennings B, Dhanani S, Volpi E, Esser KA, Rasmussen BB: Expression of growth-related genes in young and older human skeletal muscle following an acute stimulation of protein synthesis. J Appl Physiol 2009, 106:1403-1411.

57. Kim JS, Kosek DJ, Petrella JK, Cross JM, Bamman MM: Resting and loadinduced levels of myogenic gene transcripts differ between older adults with demonstrable sarcopenia and young men and women. J Appl Physiol 2005, 99:2149-2158.

58. Kosek DJ, Kim JS, Petrella JK, Cross JM, Bamman MM: Efficacy of 3 days/wk resistance training on myofiber hypertrophy and myogenic mechanisms in young vs. older adults. J Appl Physiol 2006, 101:531-544.

59. Welle S, Bhatt K, Shah B, Thornton C: Insulin-like growth factor-1 and myostatin mRNA expression in muscle: comparison between 62-77 and 21-31 yr old men. Exp Gerontol 2002, 37:833-839.

60. Gonzalez-Cadavid NF, Taylor WE, Yarasheski K, Sinha-Hikim I, Ma K, Ezzat S, Shen R, Lalani R, Asa S, Mamita M, Nair G, Arver S, Bhasin S: Organization of the human myostatin gene and expression in healthy men and HIVinfected men with muscle wasting. Proc Natl Acad Sci U S A 1998, 95:14938-14943.

61. Hittel DS, Berggren JR, Shearer J, Boyle K, Houmard JA: Increased secretion and expression of myostatin in skeletal muscle from extremely obese women. Diabetes 2009, 58:30-38.

62. Biolo G, Fleming RY, Maggi SP, Nguyen TT, Herndon DN, Wolfe RR: Inverse regulation of protein turnover and amino acid transport in skeletal muscle of hypercatabolic patients. J Clin Endocrinol Metab 2002, 87:3378-3384

63. Balagopal P, Rooyackers OE, Adey DB, Ades PA, Nair KS: Effects of aging on in vivo synthesis of skeletal muscle myosin heavy-chain and sarcoplasmic protein in humans. Am J Physiol 1997, 273:E790-800.
64. Hasten DL, Pak-Loduca J, Obert KA, Yarasheski KE: Resistance exercise acutely increases $\mathrm{MHC}$ and mixed muscle protein synthesis rates in 78-84 and 23-32 yr olds. Am J Physiol Endocrinol Metab 2000, 278:E620-626

65. Toth MJ, Matthews DE, Tracy RP, Previs MJ: Age-related differences in skeletal muscle protein synthesis: relation to markers of immune activation. Am J Physiol Endocrinol Metab 2005, 288:E883-891.

66. Atherton PJ, Etheridge T, Watt PW, Wilkinson D, Selby A, Rankin D, Smith K, Rennie MJ: Muscle full effect after oral protein: time-dependent concordance and discordance between human muscle protein synthesis and mTORC1 signaling. Am J Clin Nutr 2010, 92:1080-1088.

67. Bohe J, Low A, Wolfe RR, Rennie MJ: Human muscle protein synthesis is modulated by extracellular, not intramuscular amino acid availability: a dose-response study. J Physiol 2003, 552:315-324.

68. Mittendorfer B, Andersen JL, Plomgaard P, Saltin B, Babraj JA, Smith K, Rennie MJ: Protein synthesis rates in human muscles: neither anatomical location nor fibre-type composition are major determinants. J Physiol 2005, 563:203-211.

doi:10.1186/2042-6410-3-11

Cite this article as: Smith et al: Sexually dimorphic effect of aging on skeletal muscle protein synthesis. Biology of Sex Differences 2012 3:11.

\section{Submit your next manuscript to BioMed Central and take full advantage of:}

- Convenient online submission

- Thorough peer review

- No space constraints or color figure charges

- Immediate publication on acceptance

- Inclusion in PubMed, CAS, Scopus and Google Scholar

- Research which is freely available for redistribution

Submit your manuscript at www.biomedcentral.com/submit
C Biomed Central 